ISSN 1678-3921

Journal homepage: www.embrapa.br/pab

For manuscript submission and journal contents, access: www.scielo.br/pab
Lucas Pedro Gonçalves Junior ${ }^{(1)}$ (D), Bernardo Santos Lara ${ }^{(1)}$ (DD, Samuel Alves de Carvalho(1) (iD), Carlos Augusto Gomes Leal(2) (D), Kleber Campos Miranda Filho(1) (D), Henrique César Pereira Figueiredo(2) (D) and Ronald Kennedy Luz ${ }^{(1 凶)}$ (iD)

(1) Universidade Federal de Minas Gerais, Escola de Veterinária, Departamento de Zootecnia, Laboratório de Aquacultura, Avenida Antônio Carlos, № 6.627, CEP 31270-901 Belo Horizonte, MG, Brazil. E-mail: juniorvezula@hotmail.com, bernardolara_91@hotmail.com, samuel@rivierapescados.com, kleber08@gmail.com, luzrk@yahoo.com

(2)Universidade Federal de Minas Gerais, Escola de Veterinária, Departamento de Medicina Veterinária Preventiva, Laboratório de Doenças de Animais Aquáticos, Avenida Antônio Carlos, № 6.627, CEP 31270-901 Belo Horizonte, MG, Brazil. E-mail: carlosleal@vet.ufmg.br, figueiredoh@yahoo.com

$\bowtie$ Corresponding author

Received

February 12, 2020

Accepted

March 31, 2020

How to cite GONÇALVES JUNIOR, L.P.; LARA, B.S.; CARVALHO, S.A. de; LEAL, C.A.G.; MIRANDA FILHO, K.C.; FIGUEIREDO, H.C.P.; LUZ, R.K. Ultraviolet radiation and water salinization on recirculating aquaculture systems. Pesquisa Agropecuária Brasileira, v.55, e01804, 2020. DOI: https://doi.org/10.1590/S1678-3921. pab2020.v55.01804.

\section{Ultraviolet radiation and water salinization on recirculating aquaculture systems}

\begin{abstract}
The objective of this work was to evaluate the effects of ultraviolet radiation (UV) and water salinity on nitrification, water quality, bacterial load, and juvenile tilapia growth in recirculating aquaculture systems (RASs). The experimental period was divided into two phases. The first one lasted 20 days and evaluated the effects of salinity $\left(0\right.$ and $\left.2 \mathrm{~g} \mathrm{~L} \mathrm{~L}^{-1}\right)$ and $\mathrm{UV}$ (with or without) on water quality during the period of substrate colonization by nitrifying bacteria. In the second phase, after the storage of juvenile tilapia, the effects of the same experimental factors were evaluated on water quality, bacterial load, and fish growth performance. The RASs employed were efficient for ammonia removal, regardless of the treatments used. During the experimental period, the nitrite concentrations increased linearly, with a more pronounced increase after fish storage until 30 days of the experiment. There were no significant effects of UV, salinity, or the interaction of both on total ammonia, nitrite, and alkalinity. The low levels of salinity $\left(2 \mathrm{~g} \mathrm{~L}^{-1}\right)$ and UV did not affect the nitrification process and fish performance. The use of UV is efficient to reduce the bacterial load of recirculating aquaculture systems.
\end{abstract}

Index terms: Oreochromis niloticus, ammonia, bacterial load, biofilter, nitrite.

\section{Radiação ultravioleta e salinização da água em sistemas de aquicultura com recirculação de água}

Resumo - O objetivo deste trabalho foi avaliar os efeitos da radiação ultravioleta (UV) e da salinidade da água sobre a nitrificação, a qualidade da água, a carga bacteriana e o crescimento de juvenis de tilápia, em sistemas de aquicultura com recirculação de água (SRAs). O período experimental foi dividido em duas fases. A primeira durou 20 dias e avaliou os efeitos da salinidade $\left(0\right.$ e $\left.2 \mathrm{~g} \mathrm{~L}^{-1}\right)$ e radiação UV (com ou sem) sobre a qualidade da água, durante o período de colonização do substrato por bactérias nitrificantes. Na segunda fase, após estocagem dos juvenis de tilápia, avaliaram-se os efeitos dos mesmos fatores experimentais sobre a qualidade da água, a carga bacteriana e o desempenho dos peixes. Os SRAs empregados foram eficientes na remoção da amônia, independentemente dos tratamentos utilizados. Durante o período experimental, as concentrações de nitrito aumentaram de forma linear, com um aumento mais acentuado após o armazenamento dos peixes até 30 dias do experimento. Não houve efeitos significativos da UV, da salinidade ou da interação de ambas sobre amônia total, nitrito e alcalinidade. Os baixos níveis de salinidade $\left(2 \mathrm{~g} \mathrm{~L}^{-1}\right)$ e UV não afetaram o processo de nitrificação e o desempenho dos peixes. O uso da UV é eficiente na redução da carga bacteriana dos sistemas de aquicultura com recirculação de água.

Termos para indexação: Oreochromis niloticus, amônia, carga bacteriana, biofiltro, nitrito. 


\section{Introduction}

The implementation of recirculating aquaculture systems (RASs) has become an appealing alternative for aquaculture because of the need to reuse water and reduce water waste. Recirculating aquaculture systems provide a greater stability of water quality (Lyssenko \& Wheaton, 2006), increasing the control on the spread of pathogens (Németh et al., 2013) and intensification of production (Al-Hafedh et al., 2003).

The accumulation of nitrogen compounds is one of the main problems related to water quality throughout the crop in aquaculture, and the ability to remove these compounds is essential to maintain growth and survival of aquatic animals (Martins et al., 2009). In RASs, the withdrawal of the suspended organic matter by mechanical filter and biofilters are used to oxidize ammonia to nitrite $\left(\mathrm{NO}_{2}^{-}\right)$and, subsequently, to nitrate $\left(\mathrm{NO}_{3}{ }^{-}\right)$, by the action of nitrifying autotrophic bacteria (Hamlin et al., 2008).

Moreover, recirculating aquaculture systems demand preventive measures to avoid the spread of disease. Therefore, the disinfection of water with ultraviolet (UV) radiation has been widely used to control fungi, viruses, and bacteria (Summerfelt et al., 2009; Gullian et al., 2012). For the process to occur effectively, factors such as UV intensity (Summerfelt et al., 2009) and the absence of particulate matter (Gullian et al., 2012) must be taken into consideration. Salt can also be used for disease prevention (Németh et al., 2013); moreover, it can reduce the toxic effects of nitrogenous compounds (Sampaio et al., 2002), which are common in RASs. Thus, the brackish water has been used for freshwater fish with satisfactory results (Sampaio et al., 2002; Luz et al., 2013; Jomori et al., 2013; Németh et al., 2013). Studies on many species of fish have shown that the addition of $2 \mathrm{~g} \mathrm{~L}^{-1}$ salt improves fish performance and survival (Santos \& Luz, 2009; Luz et al., 2012, 2013; Jomori et al., 2013). The last mentioned authors also associated the beneficial effects of salt with the energy expenditure required by the ionic and osmotic regulation, which is higher in freshwater than in salt water; their studies evaluated the use of salinized water for the production of freshwater fish and UV for disinfection. However, the effects of the combination of these two factors in RASs have not been investigated yet. It is likely that this strategy may enable the reduction of pathogenic bacteria count in water (Summerfelt et al., 2009; Gullian et al., 2012), without affecting the nitrification process (Park et al., 2001; Lyssenko \& Wheaton, 2006), and improving the zootechnical performance (Luz et al., 2013).

The objective of this work was to evaluate the effects of UV radiation and water salinity on nitrification, water quality, bacterial load, and fish growth performance in recirculating aquaculture systems (RASs).

\section{Materials and methods}

The experiment was carried out at the Aquaculture Laboratory, in the Universidade Federal de Minas Gerais (UFMG). For each treatment, four RASs (mechanical filter, biological filter, return reservoir, and UV filter) and four $30 \mathrm{~L}$ cultivation tanks were used. Each RAS was considered as an experimental unit. The cultivation basins were adapted with a water outlet located in the center and an air diffuser attached to the central blower. Water was directed to a gravity filtration system. The mechanical filter was composed of a glass wool blanket fixed to a support $(35 \times 25 \times 15$ $\mathrm{cm}$ ), while the biological filter, of the same dimensions, was filled with $8 \mathrm{~L}$ gravel (1 $\mathrm{cm}$ average diameter) for fixing of nitrifying bacteria. The return tank $(80 \times 60 \times 45$ $\mathrm{cm})$, with $120 \mathrm{~L}$ useful volume, was equipped with a submersible pump (Boyu Fp48, Guangdong, China) of $2,100 \mathrm{~L} \mathrm{~h}^{-1}$ flow, and a heating system $(300 \mathrm{~W}$ power rating) with a temperature controller.

In the treatments in which UV radiation was evaluated, a UV filter model UV-C Clarifying CUV - 107 (Sunsun Group Co., Zhoushan City, Zhejiang Province, China) with $7 \mathrm{~W}$ power rating was coupled between the return reservoir and the cultivation basins. Systems with brackish water had $2 \mathrm{~g} \mathrm{~L}^{-1}$ salinity, using coarse salt ( $\mathrm{NaCl}$ ) (Salt Arroba, Macau, RN, Brazil). During the experiment, the average salinity values were $0.15 \pm 0.10 \mathrm{~g} \mathrm{~L}^{-1}$ for $\mathrm{S} 0$ and $2.00 \pm 0.01 \mathrm{~g} \mathrm{~L}^{-1}$ for S2 treatments, measured with a multiparameter device (Hanna HI-98130, Mumbai, India).

The experimental period was divided into two phases of 20 days. In the first one, the effect of treatments was evaluated on water quality during the period of colonization of the substrate by nitrifying bacteria. In the second phase, the effects of the interaction between UV and salt on the evaluated parameters were assessed, after fish were stocked in the RASs.

In the first day of the first phase, $69 \mathrm{~mL}$ of ammonium chloride $\left(\mathrm{NH}_{4} \mathrm{Cl}\right)$ was added to each

Pesq. agropec. bras., Brasília, v.55, e01804, 2020

DOI: 10.1590/S1678-3921.pab2020.v55.01804 
RAS, which corresponded to $3.5 \mathrm{mg} \mathrm{L}^{-1}$ ammonia concentration in each system. The systems remained without the addition of new water forl7 days from the beginning of the experiment; after this period, $50 \mathrm{~L}$ water were added to each RAS to replace water lost by evaporation.

After the substrate colonization by nitrifying bacteria in the first phase, corresponding to 20 days, 320 juvenile Nile tilapia (Oreochromis niloticus L.) were stocked in the cultivation tanks. Each RAS received 20 animals with $261.46 \pm 17.1 \mathrm{~g}$ average mass. Fish were fed at $3 \%$ body weight, twice a day, with $1.2 \mathrm{~mm}$ commercial feed (Fri-Ribe, Brazil) of $40 \%$ crude protein. At this stage, $10 \mathrm{~L}$ water was siphoned daily from each RAS, and the volume was restored immediately to maintain salinity. Due to evaporation, $30 \mathrm{~L}$ water were added to each RAS. Final fish mass, mass gain, and feed conversion (FC) were determined at the end of this experimental phase.

During the two experimental phases, measurements were performed twice a day for $\mathrm{pH}$, using a multiparameter device (Hanna HI98130), and dissolved oxygen and temperature, respectively measured using a dissolved-oxygen meter (AZ 8403, AZ Instrument Corp., Taiwan, China) and an oxygen meter (Politerm 60, São Paulo, SP, Brazil). Every five days, water samples were collected from the reservoir tank of each RAS for ammonia, nitrite and alkalinity analyses. Ammonia and nitrite analyses were performed following Unesco (1983) protocols and Bendschneider \& Robinson (1952), respectively, using a spectrophotometer (Biochrom Libra S22, Biochrom instruments, Cambridge, UK). Alkalinity was analyzed following the APHA/AAWWA/WEF (Eaton et al., 1995) protocol.

Four water samples were taken from each cultivation tank. The first sampling was performed 12 hours after the operation start of the RAS. The following two samples were taken at days 10 and 20 from the beginning of the experiment. The last sample was taken at the end of experimental phase 2, after 40 days. The samples were collected in sterile Falcon tubes, and they were immediately subjected to bacteriological protocols. For total bacterial count, the Miles-Misra method (Quinn et al., 2005) was used, employing a culture medium of trypticase soy agar (TSA). The plates were incubated at $28^{\circ} \mathrm{C}$ for 24 hours, and bacterial concentrations were determined by CFUs (colony-forming unit $\mathrm{mL}^{-1}$ ).

All data were tested for normality (KolmogorovSmirnov) and homogeneity of variances (Levene). The results were analyzed using the analysis of variation at $5 \%$ probability, in a completely randomized design, with four replicates, and the phase factor was considered as a subdivided plot over time. For temperature, $\mathrm{pH}$, and dissolved oxygen, a $2 \times 2 \times 2$ factorial arrangement was adopted, with two levels of the ultraviolet radiation factor (with, or without), two levels of the salinity factor $\left(0\right.$ and $\left.2 \mathrm{~g} \mathrm{~L}^{-1}\right)$, and two levels of the phase factor (phase 1 and phase 2), constituting eight treatments. For alkalinity (Alk), total ammonia (TA), and nitrite $\left(\mathrm{mg} \mathrm{L}^{-1}\right)$, the $2 \times 2 \times 8$ factorial arrangement was used, that is, two levels of the ultraviolet radiation factor (with, or without), two levels of the salinity factor $\left(0\right.$ and $\left.2 \mathrm{~g} \mathrm{~L}^{-1}\right)$, and eight levels of time factor $(5,10,15,20,25,30,35$, and 40 days), composing 32 treatments. For the bacteria count variable, the $2 \times 2 \times 4$ factorial arrangement was used, that is, two levels of ultraviolet radiation factor (with, or without), two levels of the salinity factor $\left(0\right.$ and $\left.2 \mathrm{~g} \mathrm{~L}^{-1}\right)$, and four levels of the time factor $(1,10,20$, and 40 days), constituting 16 treatments. For the results for survival (S), final mass (FB), mass gain (BG), and feed conversion (FC), during the second experimental phase, a $2 \times 2$ factorial arrangement was used, with two levels of the ultraviolet radiation factor (with, or without), and two levels of the salinity factor ( 0 and 2 $\left.\mathrm{g} \mathrm{L}^{-1}\right)$. To evaluate the effect of salinity and ultraviolet radiation factors, the Tukey's test was used, at 5\% probability, to compare the means. The effect of time was assessed by regression analysis, at 5\% probability. All results were processed using Sisvar 5.7 software (Universidade Federal de Lavras, Lavras, MG).

\section{Results and Discussion}

During the experimental period, the addition of salt increased the $\mathrm{pH}$; however, no effect of UV radiation, or the interaction between factors could be observed (Table 1). These responses can be attributed to the effect of salinity on bacterial colonies present in water, which may have affected $\mathrm{pH}$. This hypothesis is supported by the possibility that changes in water quality parameters, such as salinity, may affect bacterial activity in RAS (Park et al., 2001; Lyssenko \& 
Wheaton, 2006). Water temperature was similar for all treatments. The reduction of water $\mathrm{pH}$ throughout the phase 1 to phase 2 can be attributed to the acidifying action of $\mathrm{CO}_{2}$ accumulation from the decomposition of organic matter and fish respiration (Al-Hafedh et al., 2003; Hamlin et al., 2008). However, pH values remained within the optimum range for raising tilapia (El-Sheriff \& El-Feky, 2009; Qiang et al., 2011), and optimum action of nitrifying bacteria (from 7.5 to 9.0) (Lyssenko \& Wheaton, 2006).

The reduction of dissolved oxygen values in the second experimental phase was clearly due to oxygen consumption by fish, oxidation of food residues and waste, as well as the increase of bacterial activity by the increase of nitrogen compounds through the daily feed intake. However, dissolved oxygen remained within ideal levels for the functioning of the biofilter, during the two experimental phases (Table 1). According to Chen et al. (2006), the oxidation of ammonia to nitrate, caused by nitrifying bacteria, can occur in dissolved oxygen concentrations close to $1 \mathrm{mg} \mathrm{L}^{-1}$, although the optimal level is higher than $4 \mathrm{mg} \mathrm{L}^{-1}$. Nitrifying bacteria are tolerant to variations of water quality; however, the maximum efficiency of the removal of nitrogen compounds occurs when physical and chemical parameters of water are at the optimum condition for these bacteria (Colt, 2006).

The lowest value for alkalinity was observed in the treatment without UV (Table 2). Water alkalinity decreased linearly at $5 \%$ probability, between the $5^{\text {th }}$ and $40^{\text {th }}$ experimental days. No significant effects of

Table 1. Dissolved oxygen (DO), $\mathrm{pH}$, and water temperature, for salinity, UV, and experimental phase ${ }^{(1)}$.

\begin{tabular}{lccc}
\hline Treatment & $\mathrm{DO}\left(\mathrm{mg} \mathrm{L}^{-1}\right)$ & $\mathrm{pH}$ & Temperature $\left({ }^{\circ} \mathrm{C}\right)$ \\
\hline Salinity & & & \\
$0\left(\mathrm{~g} \mathrm{~L}^{-1}\right)$ & $6.8 \pm 1.0 \mathrm{a}$ & $7.9 \pm 0.4 \mathrm{~b}$ & $27.3 \pm 0.6 \mathrm{a}$ \\
$2\left(\mathrm{~g} \mathrm{~L}^{-1}\right)$ & $6.8 \pm 1.1 \mathrm{a}$ & $8.2 \pm 0.3 \mathrm{a}$ & $27.0 \pm 0.7 \mathrm{a}$ \\
\hline UV & & & \\
With UV & $6.8 \pm 1.1 \mathrm{a}$ & $8.1 \pm 0.5 \mathrm{a}$ & $26.9 \pm 0.6 \mathrm{a}$ \\
Without UV & $6.8 \pm 1.1 \mathrm{a}$ & $8.1 \pm 0.4 \mathrm{a}$ & $27.4 \pm 0.7 \mathrm{a}$ \\
\hline Phase & & & \\
Phase 1 & $7.8 \pm 0.1 \mathrm{a}$ & $8.4 \pm 0.1 \mathrm{a}$ & $27.0 \pm 0.7 \mathrm{a}$ \\
Phase 2 & $5.8 \pm 0.1 \mathrm{~b}$ & $7.7 \pm 0.3 \mathrm{~b}$ & $27.2 \pm 0.7 \mathrm{a}$ \\
\hline CV $(\%)$ & 1.6 & 2.4 & 2.5 \\
\hline
\end{tabular}

${ }^{(1)}$ Means followed by equal letters, do not differ by Tukey's test, at $5 \%$ probability. CV, coefficient of variation. Phase 1, until 20 days, and phase 2 , from 21 to 40 days. salinity, or interaction between factors, was observed for alkalinity. Alkalinity, the total bases in water, is of underlying importance for $\mathrm{pH}$ stability. The significant effect on alkalinity as a function of time may be attributed to the increase of the production of nitrogen compounds and organic matter, and to carbonate consumption by bacteria. Alkalinity is involved in the complete oxidation of ammonia, when carbonate and bicarbonate are used as nutrients by nitrifying bacteria (Chen et al., 2006). For this reason, there is a reduction of total alkalinity and $\mathrm{pH}$, making it necessary to correct alkalinity during cultivation (Al-Hafedh et al., 2003; Hamlin et al., 2008; Martins et al., 2009). In the present work, despite the reduction, alkalinity remained higher than $50 \mathrm{mg} \mathrm{L}^{-1}$, which is appropriate for tilapia farming and for the proper biofilter functioning (Chen et al., 2006; Hamlin et al., 2008). Because of this fact, no corrections were performed during the experimental period, but future studies of longer durations will likely need to make such corrections.

Table 2. Alkalinity, total ammonia, and nitrite for salinity, $\mathrm{UV}$, and experimental days ${ }^{(1)}$.

\begin{tabular}{|c|c|c|c|}
\hline Treatment & $\begin{array}{l}\text { Alkalinity } \\
\left(\mathrm{mg} \mathrm{L}^{-1}\right)\end{array}$ & $\begin{array}{l}\text { Total ammonia } \\
\quad\left(\mathrm{mg} \mathrm{L}^{-1}\right)\end{array}$ & $\begin{array}{l}\text { Nitrite } \\
\left(\mathrm{mg} \mathrm{L}^{-1}\right)\end{array}$ \\
\hline \multicolumn{4}{|l|}{ Salinity } \\
\hline $0 \mathrm{~g} \mathrm{~L}^{-1}$ & $72.3 \pm 18.3 \mathrm{a}$ & $0.2 \pm 0.4 \mathrm{a}$ & $3.1 \pm 4.0 \mathrm{a}$ \\
\hline $2 \mathrm{~g} \mathrm{~L}^{-1}$ & $75.3 \pm 18.3 \mathrm{a}$ & $0.2 \pm 0.5 \mathrm{a}$ & $3.6 \pm 4.4 \mathrm{a}$ \\
\hline \multicolumn{4}{|l|}{ UV } \\
\hline With UV & $77.0 \pm 16.5 \mathrm{a}$ & $0.2 \pm 0.4 \mathrm{a}$ & $3.6 \pm 4.3 \mathrm{a}$ \\
\hline Without UV & $71.9 \pm 18.5 b$ & $0.2 \pm 0.5 \mathrm{a}$ & $3.0 \pm 4.2 \mathrm{a}$ \\
\hline \multicolumn{4}{|l|}{ Days ${ }^{(2)}$} \\
\hline Day 5 & $89.1 \pm 4.4$ & $1.2 \pm 0.3$ & $0.1 \pm 0.2$ \\
\hline Day 10 & $84.1 \pm 9.7$ & $0.4 \pm 0.4$ & $1.5 \pm 0.1$ \\
\hline Day 15 & $82.5 \pm 7.9$ & $0.0 \pm 0.0$ & $2.4 \pm 1.0$ \\
\hline Day 20 & $90.9 \pm 11.5$ & $0.0 \pm 0.0$ & $1.4 \pm 0.7$ \\
\hline Day 25 & $79.7 \pm 8.2$ & $0.0 \pm 0.0$ & $4.4 \pm 2.4$ \\
\hline Day 30 & $56.6 \pm 7.4$ & $0.0 \pm 0.0$ & $8.7 \pm 6.2$ \\
\hline Day 35 & $54.7 \pm 9.3$ & $0.0 \pm 0.0$ & $5.7 \pm 5.6$ \\
\hline Day 40 & $52.8 \pm 18.1$ & $0.0 \pm 0.0$ & $2.3 \pm 2.3$ \\
\hline CV (\%) & 13.84 & 99.4 & 136.5 \\
\hline \multicolumn{4}{|c|}{$\begin{array}{l}\text { (1) Means followed by equal letters, do not differ by Tukey's test, at } 5 \% \\
\text { probability. CV, coefficient of variation. Phase } 1 \text {, until } 20 \text { days, and phase } \\
2 \text {, from } 21 \text { to } 40 \text { days. (2) Regression equations: alkalinity, linear effect at } \\
5 \% \text { probability; } y=-1.1659 x+100.02, \mathrm{R}^{2}=0.77 \text {. Total ammonia, quadratic } \\
\text { effect at } 5 \% \text { probability; } y=0.0021 x^{2}-0.1189 x+1.545, R^{2}=0.85 \text {. Nitrite, } \\
\text { linear effect at } 5 \% \text { probability; } y=0.1387 x+0.1963, R^{2}=0.36 \text {. }\end{array}$} \\
\hline
\end{tabular}


During the experiment, no significant effects of UV, water salinity, or the interaction between them, were observed on ammonia and nitrite (Table 2). The absence of UV effect on ammonia and nitrite levels in fresh, or salinized water, can be attributed to the fact that nitrifying bacteria are located mainly in the biofilter, and not in UV water, as reported by other authors (Summerfelt et al., 2009; Gullian et al., 2012). Despite the influence that salinity may have on nitrification (Lyssenko \& Wheaton, 2006), in the present study, the low-salinity concentration, in relation to freshwater, did not affect the effectiveness of nitrifying bacteria. However, according to a study by Park et al. (2001), an increased salinity from 0 to $30 \mathrm{~g} \mathrm{~L}^{-1}$ caused $30 \%$ decrease of the nitrification efficiency; nonetheless, bacterial activity returned to normal after 10 days of operation.

The RASs employed were efficient in the ammonia removal, irrespective of the treatments used. The ammonia concentration added to each system (3.5 $\left.\mathrm{mg} \mathrm{L}^{-1}\right)$ in the first day, was lower five days after starting the experiment, and near $0 \mathrm{mg} \mathrm{L}^{-1}$ within 15 days, after which it remained almost nonexistent even after fish stocking and feeding. The nitrite concentrations increased linearly during the experimental period, with a more pronounced increase after fish stocking until 30 days of the experiment. Ammonia accumulation is one of the main problems faced by aquatic production systems. In the present study, the RASs were efficient at keeping total ammonia within the concentration recommended for tilapia cultivation (Benli et al., 2008). Al-Hafedh et al. (2003) also reported values of total ammonia lower than $1 \mathrm{mg} \mathrm{L}^{-1}$ TA-N (total ammonia - nitrogen) in a RAS during tilapia cultivation. Our results show the need of a greater system uptime for the efficient removal of nitrite. Ammonia and nitrite concentrations in RASs have been reported by other studies evaluating the biofilter efficiency (Kuhn et al., 2010).

On the $30^{\text {th }}$ day, nitrite concentration reached values of approximately $9 \mathrm{mg} \mathrm{L}^{-1} \mathrm{NO}_{2}{ }^{-} \mathrm{N}$. Nitrite concentration in the tanks was actually too high, as a concentration lower than $0.2 \mathrm{mg} \mathrm{L}^{-1}$ is suggested for tilapia comfort in cultivation (Yanbo et al., 2006). This result was higher than the $2 \mathrm{mg} \mathrm{L}^{-1} \mathrm{NO}_{2}{ }^{-} \mathrm{N}$ reported by Shnel et al. (2002), and the $0.5 \mathrm{mg} \mathrm{L}^{-1} \mathrm{NO}_{2}{ }^{-} \mathrm{N}$ reported by Al-Hafedh et al. (2003), who reared tilapia in RAS. However, in the present experiment, the time of exposure was short because the nitrite concentration reduced after 30 days. The lethal concentration (LC50-96 hours) of nitrite for tilapia juveniles was estimated at $81 \mathrm{mg} \mathrm{L}^{-1}$ (Atwood et al., 2001), which shows the tolerance of tilapia to highnitrite concentrations.

For the bacteria count during the RASs operation, a significant effect was recorded for UV only, with lower bacterial counts in the presence of UV (Table 3). No effect was observed for salinity, sample time, or interaction between factors. Our results corroborate those of some authors for the use of UV, which was previously found to be effective in the reduction of bacterial load, in freshwater (Sharrer \& Summerfelt, 2007; Gullian et al., 2012), and saltwater (Attramadal et al., 2012). Future studies assessing which species of bacteria are affected by UV and salt would be important. It is known that salt can be used in the prevention and control of diseases (Németh et al., 2013), to decrease the toxicity of nitrogenous compounds and to reduce the stress of animals (Sampaio et al., 2002).

Survival, final mass, mass gain, and feed conversion of tilapia were not affected by UV radiation nor water salinity in the evaluated time. In addition, there was no interaction between these factors (Table 4). The survival and growth performance data were satisfactory and similar in all treatments. Working with larvae of tilapia held in fresh and brackish water $\left(2 \mathrm{~g} \mathrm{~L}^{-1}\right.$ salt), Luz et al. (2013) reported similar results. Another

Table 3. Bacteria count for salinity, UV, and experimental days $^{(1)}$.

\begin{tabular}{lc}
\hline Treatment & Bacteria count $\left(\mathrm{CFU} \mathrm{mL}^{-1}\right)$ \\
\hline Salinity & \\
$0 \mathrm{~g} \mathrm{~L}^{-1}$ & $2,482.8 \mathrm{a}$ \\
$2 \mathrm{~g} \mathrm{~L}^{-1}$ & $5,732.2 \mathrm{a}$ \\
\hline $\mathrm{UV}$ & \\
With UV & $1,911.6 \mathrm{~b}$ \\
Without UV & $6,487.4 \mathrm{a}$ \\
\hline Days & \\
Day 1 & $2,975.0$ \\
Day 10 & $2,211.3$ \\
Day 20 & $6,762.5$ \\
Day 40 & $4,481.3$ \\
\hline Coefficient of variation $(\%)$ & 162.3 \\
\hline
\end{tabular}

(1)Means followed by equal letters, do not differ by Tukey's test, at $5 \%$

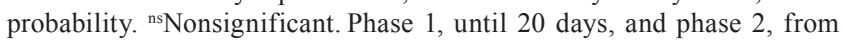
21 to 40 days. 
Table 4. Means ( \pm standard deviation) for survival, final mass, mass gain and feed conversion (FC), during the second experimental phase ${ }^{(1)}$.

\begin{tabular}{lcccc}
\hline Treatment & $\begin{array}{c}\text { Survival } \\
(\%)\end{array}$ & $\begin{array}{c}\text { Final mass } \\
(\mathrm{g})\end{array}$ & $\begin{array}{c}\text { Mass gain } \\
(\mathrm{g})\end{array}$ & $\mathrm{FC}$ \\
\hline With UV & $88.3 \pm 9.8 \mathrm{a}$ & $371.3 \pm 49.0 \mathrm{a}$ & $114.4 \pm 42.4 \mathrm{a}$ & $1.7 \pm 0.8 \mathrm{a}$ \\
Without UV & $90.0 \pm 7.1 \mathrm{a}$ & $383.9 \pm 62.4 \mathrm{a}$ & $118.7 \pm 44.4 \mathrm{a}$ & $1.6 \pm 0.6 \mathrm{a}$ \\
$0 \mathrm{~g} \mathrm{~L}^{-1}$ & $89.3 \pm 8.9 \mathrm{a}$ & $373.6 \pm 65.0 \mathrm{a}$ & $111.7 \pm 47.79 \mathrm{a}$ & $1.7 \pm 0.7 \mathrm{a}$ \\
$2 \mathrm{~g} \mathrm{~L}^{-1}$ & $89.2 \pm 8.0 \mathrm{a}$ & $381.9 \pm 49.2 \mathrm{a}$ & $121.1 \pm 39.1 \mathrm{a}$ & $1.5 \pm 0.6 \mathrm{a}$ \\
\hline $\mathrm{CV}(\%)$ & 8.7 & 13.9 & 34.3 & 39.8 \\
\hline
\end{tabular}

(1)Means followed by equal letters, do not differ by Tukey's test, at 5\% probability. $\mathrm{CV}$, coefficient of variation.

study showed the possibility of growing adult tilapia in salinized water $\left(8 \mathrm{~g} \mathrm{~L}^{-1}\right)$, with $98 \%$ survival rate (Chowdhury et al., 2006). Moreover, tilapia is known to show a wide tolerance to water-salinity gradients (Iqbal et al., 2012), and it can tolerate salinity up to $20 \mathrm{~g} \mathrm{~L}^{-1}$, when adapted by a gradual salinity increase (Sousa et al., 2010). The values (1.7) we found for feed conversion (FC) were better than those reported for other tilapia reared in RASs. Al-Hafedh et al. (2003) evaluated different biofilters, and they found $\mathrm{FC}=$ 1.90, using fish of $100.0 \mathrm{~g}$. Shnel et al. (2002) found FC $=2.03$ for a system with zero water exchange, using fish of $28.4 \mathrm{~g}$. The difference between these studies and ours may be associated with the lower initial weight of the animals used (approximately $13 \mathrm{~g}$ ).

\section{Conclusions}

1. The use of low salinity and ultraviolet (UV) radiation do not affect the nitrification process.

2. The use of UV is efficient to decrease the bacterial load in recirculating aquaculture systems.

3. Zootechnical performance is not affected by the practice of the combined use of UV radiation and low salinity.

\section{Acknowledgments}

To Coordenação de Aperfeiçoamento de Pessoal de Nível Superior (Capes), Conselho Nacional de Desenvolvimento Científico e Tecnológico (CNPq), and Fundação de Amparo à Pesquisa do Estado de Minas Gerais (Fapemig), for financial support. R.K. Luz is research fellowship of CNPq (Process no. 308547/2018-7).

\section{References}

AL-HAFEDH, Y.S.; ALAM, A.; ALAM, M.A. Performance of plastic biofilter media with different configuration in a water recirculation system for the culture of Nile tilapia (Oreochromis niloticus). Aquacultural Engineering, v.29, p.139-154, 2003. DOI: https://doi.org/10.1016/S0144-8609(03)00065-7.

ATTRAMADAL, K.J.K.; ØIE, G.; STØRSETH, T.R.; ALVER, M.O.; VADSTEINS, O.; OLSEN, Y. The effects of moderate ozonation or high intensity UV-irradiation on the microbial environment in RAS for marine larvae. Aquaculture, v.330-333, p.121-129, 2012. DOI: https://doi.org/10.1016/j. aquaculture.2011.11.042.

ATWOOD, H.L.; FONTENOT, Q.C.; TOMASSO, J.R.; ISELY, J.J. Toxicity of nitrite to Nile tilapia: effect of fish size and environmental chloride. North American Journal of Aquaculture, v.63, p.49-51, 2001. DOI: https://doi. org/10.1577/1548-8454(2001)063<0049:TONTNT>2.0.CO;2.

BENDSCHNEIDER, K.; ROBINSON, R.J. A new spectrophotometric method for the determination of nitrite in sea water. Washington: Office of Naval Research, 1952. (Technical report, n.8).

BENLI, A.Ç.K.; KÖKSAL, G.; ÖZKUL, A. Sublethal ammonia exposure of Nile tilapia (Oreochromis niloticus L.): effects on gill, liver and kidney histology. Chemosphere, v.72, p.1355-1358, 2008. DOI: https://doi.org/10.1016/j.chemosphere.2008.04.037.

CHEN, S.; LING, J.; BLANCHETON, J.-P. Nitrification kinetics of biofilm as affected by water quality factors. Aquacultural Engineering, v.34, p.179-197, 2006. DOI: https://doi.org/10.1016/j. aquaeng.2005.09.004.

CHOWDHURY, M.; YI, Y.; LIN, C.K.; EL-HAROUN, E.R. Effect of salinity on carrying capacity of adult Nile tilapia Oreochromis niloticus L. in recirculating systems. Aquaculture Research, v.37, p.1627-1635, 2006. DOI: http://doi.wiley.com/10.1111/j.1365-2109.2006.01605.x.

COLT, J. Water quality requirements for reuse systems. Aquacultural Engineering, v.34, p.143-156, 2006. DOI: https://doi.org/10.1016/j.aquaeng.2005.08.011.

EATON, A.D.; CLESCERI, L.S.; GREENBERG, A.E. (Ed.). Standard methods for the examination of water and wastewater. $19^{\text {th }}$ ed. Washington: American Public Health Association, 1995.

EL-SHERIFF, M.S.; EL-FEKY, A.M.I. Performance of Nile tilapia (Oreochromis niloticus) fingerlings. I. Effect of $\mathrm{pH}$. International Journal of Agriculture and Biology, v.11, p.297300, 2009.

GULLIAN, M.; ESPINOSA-FALLER, F.J.; NÚÑEZ, A.; LÓPEZBARAHONA, N. Effect of turbidity on the ultraviolet disinfection performance in recirculating aquaculture systems with low water exchange. Aquaculture Research, v.43, p.595-606, 2012. DOI: https://doi.org/10.1111/j.1365-2109.2011.02866.x.

HAMLIN, H.J.; MICHAELS, J.T.; BEAULATON, C.M.; GRAHAM, W.F.; DUTT, W.; STEINBACH, P.; LOSORDO, T.M.; SCHRADER, K.K.; MAIN, K.L. Comparing denitrification rates 
and carbon sources in commercial scale upflow denitrification biological filters in aquaculture. Aquacultural Engineering, v.38, p.79-92, 2008. DOI: https://doi.org/10.1016/j.aquaeng.2007.11.003.

IQBAL, K.J.; QURESHI, N.A.; ASHRAF, M.; REHMAN, M.H.U.; KHAN, N.; JAVID, A.; ABBAS, F.; MUSHTAQ, M.M.H.; RASOOL, F.; MAJEED, H. Effect of different salinity levels on growth and survival of Nile tilapia (Oreochromis Niloticus). The Journal of Animal and Plant Sciences, v.22, p.919-922, 2012.

JOMORI, R.K.; LUZ, R.K.; TAKATA, R.; FABREGAT, T.E.H.P.; PORTELA, M.C. Água levemente salinizada aumenta a eficiência da larvicultura de peixes neotropicais. Pesquisa Agropecuária Brasileira, v.48, p.809-815, 2013. DOI: https://doi.org/10.1590/ S0100-204X2013000800001.

KUHN, D.D.; DRAHOS, D.D.; MARSH, L.; FLICK JR., G.J. Evaluation of nitrifying bacteria product to improve nitrification efficacy in recirculating aquaculture systems. Aquacultural Engineering, v.43, p.78-82, 2010. DOI: https://doi.org/10.1016/j. aquaeng.2010.07.001.

LUZ, R.K.; SANTOS, A.E.H.; MELILLO FILHO, R.; TURRA, E.M.; TEIXEIRA, E. de A. Larvicultura de tilápia em água doce e água salinizada. Pesquisa Agropecuária Brasileira, v.48, p.1150-1153, 2013. DOI: https://doi.org/10.1590/S0100204X2013000800051.

LUZ, R.K.; SILVA, W. de S. e; MELILLO FILHO, R.; SANTOS, A.E.H.; RODRIGUES, L.A.; TAKATA, R.; ALVARENGA, E.R. de; TURRA, E.M. Stocking density in the larviculture of Nile tilapia in saline water. Revista Brasileira de Zootecnia, v.41, p.2385-2389, 2012. DOI: https://doi.org/10.1590/S151635982012001200001 .

LYSSENKO, C.; WHEATON, F. Impact of positive ramp shortterm operating disturbances on ammonia removal by trickling and submerged-upflow biofilters for intensive recirculating aquaculture. Aquacultural Engineering, v.35, p.26-37, 2006. DOI: https://doi.org/10.1016/j.aquaeng.2005.08.002.

MARTINS, C.I.M.; PISTRIN, M.G.; ENDE, S.S.W.; EDING, E.H.; VERRETH, J.A.J. The accumulation of substances in Recirculating Aquaculture Systems (RAS) affects embryonic and larval development in common carp Cyprinus carpio. Aquaculture, v.291, p.65-73, 2009. DOI: https://doi.org/10.1016/j. aquaculture.2009.03.001.

NÉMETH, S.; HORVÁTH, Z.; FELFÖLDI, Z.; BELICZKY, G.; DEMETER, K. The use of permitted ectoparasite disinfection methods on young pike-perch (Sander lucioperca) after transition from over-wintering lake to RAS. Aquaculture, Aquarium, Conservation \& Legislation, v.6, p.1-11, 2013.

PARK, E.-J.; SEO, J.-K.; KIM, M.-R.; JUNG, I.-H.; KIM, J.Y.; KIM, S.-K. Salinity acclimation of immobilized freshwater denitrifier. Aquacultural Engineering, v.24, p.169-180, 2001. DOI: https://doi.org/10.1016/s0144-8609(01)00062-0.

QIANG, J.; WANG, H.; LI, R.; ZHU, X.; PENG, J. Effects of acid and alkaline stress on energy metabolism of Oreochromis niloticus juveniles with different body mass. Chinese Journal of Applied Ecology, v.22, p.2438-2446, 2011.

QUINN, P.J.; MARKEY, B.K.; CARTER, M.E.; DONNELLY, W.J.C.; LEONARD, F.C. Microbiologia veterinária e doenças infecciosas. Porto Alegre: Artmed, 2005.

SAMPAIO, L.A.; WASIELESKY, W.; MIRANDAFILHO, K.C. Effect of salinity on acute toxicity of ammonia and nitrite to juvenile Mugil platanus. Bulletin of Environmental Contamination and Toxicology, v.68, p.668674, 2002. DOI: https://doi.org/10.1007/s001280306.

SANTOS, J.C.E. dos; LUZ, R.K. Effect of salinity and prey concentrations on Pseudoplatystoma corruscans, Prochilodus costatus and Lophiosilurus alexandri larviculture. Aquaculture, v.287, p.324-328, 2009. DOI: https://doi.org/10.1016/j. aquaculture.2008.10.014.

SHARRER, M.J.; SUMMERFELT, S.T. Ozonation followed by ultraviolet irradiation provides effective bacteria inactivation in a freshwater recirculating system. Aquacultural Engineering, v.37, p.180-191, 2007. DOI: https://doi.org/10.1016/j. aquaeng.2007.05.001.

SHNEL, N.; BARAK, Y.; EZER, T.; DAFNI, Z.; RIJN, J. van. Design and performance of a zero-discharge tilapia recirculating system. Aquacultural Engineering, v.26, p.191-203, 2002.

SOUSA, T.R.P. de; SANTOS, C.J.A.; SANTOS, D.L.; QUEIROZ, A.C. dos S.; MENDES, P. de P. Desempenho zootécnico da tilápia nilótica linhagem chitralada sob influência da salinidade. Revista Brasileira de Engenharia de Pesca, v.5, p.10-18, 2010. DOI: https://doi.org/10.18817/repesca.v5i1.150.

SUMMERFELT, S.T.; SHARRER, M.J.; TSUKUDA, S.M.; GEARHEART, M. Process requirements for achieving fullflow disinfection of recirculating water using ozonation and UV irradiation. Aquacultural Engineering, v.40, 17-27, 2009. DOI: https://doi.org/10.1016/j.aquaeng.2008.10.002.

UNESCO. Chemical methods for use in marine environmental monitoring. [S.1.]: UNESCO, IOC, 1983. (Intergovernmental Oceanographic Commission. Manuals and Guides; 12).

YANBO, W.; WENJU, Z.; WEIFEN, L.; ZIRONG, X. Acute toxicity of nitrite on tilapia (Oreochromis niloticus) at different external chloride concentrations. Fish Physiology and Biochemistry, v.32, p.49-54, 2006. DOI: https://doi.org/10.1007/ s10695-005-5744-2. 